\title{
Kandungan Logam Berat Timbal (Pb) pada Ikan Nila (Oreochromis niloticus) dan Ikan Bawal (Colossoma macropomum) di Sungai Winongo, Yogyakarta
}

\author{
Heavy Metal Lead on Oreochromis niloticus and Colossoma macropomum \\ in Winongo River, Yogyakarta
}

\author{
Annabelle Indryana Purwanto ${ }^{1}$, Guruh Prihatmo ${ }^{1 *}$, dan Suhendra Pakpahan ${ }^{1}$ \\ ${ }^{1}$ Fakultas Bioteknologi, Universitas Kristen Duta Wacana, Yogyakarta, Indonesia
}

\begin{abstract}
Abstrak
Sungai Winongo memiliki peran cukup penting di masyarakat kota Yogyakarta. Penelitian ini bertujuan untuk mengetahui konsentrasi $\mathrm{Pb}$ ada air, sedimen (batu, kerikil, pasir dan lempung) dan tiga organ ikan Nila (Oreochromis niloticus) serta ikan Bawal (Colossoma macropomum) yaitu organ viscera, tulang dan daging. Sampel diperoleh dari tiga titik yaitu bagian hulu, tengah dan hilir. Total 120 sampel diekstraksi menggunakan metode aqua regia digestible dengan perbandingan larutan $\mathrm{HCl}: \mathrm{HNO}_{3}(3: 1, \mathrm{v} / \mathrm{v})$ dan ekstrak dianalisis menggunakan Atomic Absorption Spectrophotometry (AAS). Ditemukan rata-rata konsentrasi $\mathrm{Pb}$ pada air $(0,054 \mathrm{mg} / \mathrm{L})$, sedimen $(38,29 \mathrm{mg} / \mathrm{kg}$ ), ikan Nila ( viscera 11,35 mg/kg; tulang 10,28 mg/kg; daging 6,46 mg/kg), dan ikan Bawal ( viscera 5,31 mg/kg; 9,85 mg/kg; daging 5,23 mg/ kg). Konsentrasi Pb pada air telah melebihi batas baku mutu PPRI No. 82 Th 2001 (0,03mg/L). Konsentrasi pada ketiga bagian ikan Nila dan Bawal yang diteliti (viscera, tulang, daging) telah melebihi batas baku mutu yang ditetapkan oleh SNI 7387:2009 (0,3 mg/kg).
\end{abstract}

Keywords : Timbal, Logam Berat, Sungai Winongo, Pencemaran, Konsentrasi

\begin{abstract}
Winongo river had important role in life of Yogyakarta citizen.This study acknowledged lead concentration of water, sediments, and three organs of Tilapia fish and Pomfret fish, they would be viscera, bones, and meat. There were 120 samples extracted by aqua regia digestible method using $\mathrm{HCl}: \mathrm{HNO}_{3}(3: 1$, $\mathrm{v} / \mathrm{v}$ ) and extract analyzed by Atomic Absoprtion Spectrophotometry (AAS) to measure Lead concentration. Found out, mean lead concentrarion on water $(0.054 \mathrm{mg} / \mathrm{L})$, sediments $(38.29 \mathrm{mg} / \mathrm{kg})$, Tilapia fish ( viscera $11.35 \mathrm{mg} / \mathrm{kg}$; bone $10.28 \mathrm{mg} / \mathrm{kg}$; meat $6.46 \mathrm{mg} / \mathrm{kg}$ ), and Pomfret fish ( viscera $5.31 \mathrm{mg} / \mathrm{kg}$; bone $9.85 \mathrm{mg} /$ $\mathrm{kg}$; meat $5.23 \mathrm{mg} / \mathrm{kg}$ ). Lead concentration on water has exceeded the maximum limit according to PPRI No. 82 Th 2001 (0.03 mg/L). Three body-parts of both fish (viscera, bone, meat) has exceeded the maximum limit of heavy metal lead according to SNI 7387:2009 $(0.3 \mathrm{mg} / \mathrm{kg})$.
\end{abstract}

Keywords: Lead, Heavy Metal, Winongo River, Pollution, Concentration

\footnotetext{
*Corresponding author:

Guruh Prihatmo

Fakultas Bioteknologi Universitas Kristen Duta Wacana, Yogyakarta

Jl. Wahidin Sudirohusodo 5-25, Yogyakarta, Indonesia, 55224

Email : Guruh.pri@gmail.com
} 


\section{Pendahuluan}

Sungai merupakan salah satu ekosistem akuatik yang sering ditemukan melintasi daerah pemukiman penduduk dan banyak dimanfaatkan oleh warga sektiar dalam beraktivitas sehari-hari seperti memancing ikan, mencuci dan anak-anak yang cukup sering berenang di sungai. Selain itu, sungai juga digunakan sebagai tempat pembuangan akhir sampah maupun limbah yang dihasilkan oleh manusia seperti limbah domestik, industri, maupun peternakan yang berada di sekitar badan sungai (Ibisch, 2009). Menurut Badan Lingkungan Hidup Daerah Istimewa Yogyakarta (2012), ditemukan macam-macam sumber pencemaran yaitu industri, rumah sakit dan perhotelan yang membuang limbah ke Sungai Winongo. Dua jenis limbah yang ditemukan di Sungai Winongo yakni limbah esensial dan nonesensial. Salah satu jenis limbah non-esensial yang terdapat pada Sungai Winongo adalah logam berat timbal (Ackerley, 2004).

Timbal merupakan logam non-esensial yang ada di alam oleh karena proses alamiah maupun aktivitas manusia seperti industri dan kendaraan berbahan bakar fosil (Grossel et al., 2005). Timbal bersifat dapat berikatan dengan material organik dan mengendap di dasar perairan seperti pada sedimen sungai (Ackerley, 2004). Timbal merupakan sebuah unsur yang 95\% bersifat anorganik dan memiliki sifat kurang larut dalam air. Oleh karena timbal berbentuk dalam partikel dalam udara sehingga tidak dapat menguap (Hutabarat, 2011). Logam berat akan bercampur pada perairan melalui proses adsorbsi dan pengenceran sebelum pada akhirnya mengendap pada substrat dasar (Moriarty, 1998). Timbal akan bertahan lama pada sedimen bahkan ketika sumber pencemarnya telah hilang. Timbal pada sedimen dasar dapat naik dan bercampur kembali pada kolom perairan dikarenakan proses pengadukan seperti perubahan densitas yang dapat menjadi faktor lepasnya ion logam berat ke perairan (Huang, 2013).

Biota air seperti ikan dapat digunakan sebagai bioindikator pada lingkungan perairan yang terakumulasi logam berat selain sedimen dan air. Hal ini dapat didukung dengan siklus hidup ikan yang mengonsumsi makanan dan absorbsi udara melalui insang pada perairan yang terakumulasi logam berat. Ikan memiliki keterbatasan dalam melakukan proses degradasi dan ekskresi logam berat. Pada konsentrai tinggi, logam berat terdistribusi dan terakumulasi pada otot, hati, saluran pencernaan serta insang sebagai jaringan metabolisme aktif. Ikan Nila merupakan ikan yang hidup melayang dalam kolom perairan dan bersifat omnivora sehingga meningkatkan potensi terpapar oleh logam berat. Akumulasi Logam berat didukung dengan proses fisiologis tubuh ikan yakni proses absorbsi logam berat yang berjalan bersamaan dengan difusi air melalui insang dan kegiatan makan yang menyebabkan distribusi logam berat ke seluruh tubuh ikan (Oktapiandi et al., 2009).

Ikan Bawal juga memiliki gaya hidup yang sama dengan ikan Nila yakni bersifat omnivora. Ikan Bawal juga memiliki toleransi yang tinggi terhadap lingkungan habitatnya dalam kondisi baik maupun kurang baik serta memiliki nafsu makan yang cukup tinggi (Arie, 2006). Ikan Bawal hidup berkoloni atau bergerombol di daerah yang memiliki aliran air yang deras maupun tenang (Khairuman dan Amri, 2008). Sungai memmpunyai peran penting sebagai sumber daya air untuk mendukung aktivitas manusia seperti pertanian, irigasi, peternakan ikan, dan wisata. Aktivitas dan eksploitasi lingkungan yang berlebihan membuat kualitas sungai menurun. Oleh karena itu, untuk mengetahui pencemaran logam berat pada sungai perlu dilakukan pengujian logam berat pada ikan sebagai bioindikator

\section{Materi dan Metode Lokasi}

Lokasi pengambilan sampel berada pada tiga titik bagian sungai Winongo, kota Yogyakarta yakni bagian hulu (Mlati Dukuh, Sangadi Ringroad Utara, -7.747931 LS; 110.358144 BT), tengah (Gang Guyup Rukun Kidul, Notoprajan, -7.801812 LS; 110.354540 BT) dan hilir (Senggotan, Tirtonirmolo Ringroad Selatan. -7.826311 LS; 110.351989 BT). 


\section{Koleksi Sampel}

Sampel yang diambil adalah air, sedimen (batu, kerikil, pasir dan lempung) dan biota air (ikan Nila dan ikan Bawal) dengan menggunakan jala pancing (jala lempar). Uji parameter fisik yang dilakukan meliputi pengukuran $\mathrm{pH}$, suhu, oksigen terlarut (DO), dan kecepatan arus.

\section{Preparasi Sampel}

Sampel ikan akan dibedakan menjadi tiga bagian yakni organ viscera, tulang dan daging masing-masing 5 replikat. Sampel bagian tubuh ikan dan sedimen akan ditimbang berat basah, kemudian dioven dalam waktu 24 jam dengan suhu $105^{\circ} \mathrm{C}$, kemudian diangin-anginkan selama 10-15 menit, ditimbang berat kering. Sampel air dengan volume $100 \mathrm{~mL}$ akan disaring menggunakan kertas saring Whatman sebelum diekstraksi.

\section{Ekstraksi}

Metode ekstraksi menggunakan aqua regia digestible. Ekstraksi sampel dilakukan dengan menambahkan aqua regia $\left(\mathrm{HCl}: \mathrm{HNO}_{3}\right.$; $3: 1 \mathrm{v} / \mathrm{v})$

\section{Analisa Data}

Pengukuran kadar $\mathrm{Pb}$ ekstrak menggunakan Spektrofotometri Serapan Atom (Atomic Absorption Spectrophotometry/ AAS). Data yang diperoleh akan diolah menggunakan software SPSS 21.

\section{Hasil}

Kelarutan logam berat timbal pada ekosistem sungai dipengaruhi oleh beberapa faktor eksternal diantara lainnya suhu, $\mathrm{pH}$, DO, dan kecepatan arus. Pada Tabel 1 dapat dilihat masing-masing hasil parameter fisika-kimia yang didapatkan dibandingkan dengan baku mutu PPRI No. 82 Th 2001.

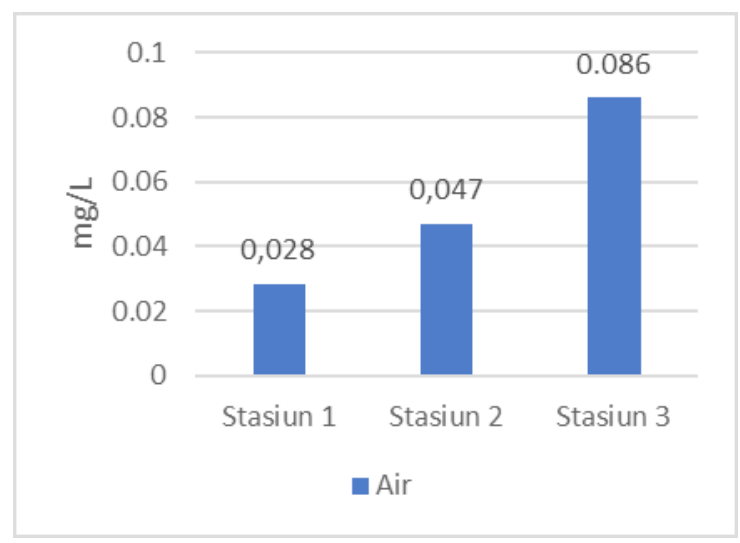

Gambar 1. Diagram Rata-rata Konsentrasi Logam Berat Timbal pada Air.

Pada Gambar 1 didapati hasil rata-rata konsentrasi logam berat timbal pada air Sungai Winongo masing-masing stasiun. Konsentrasi timbal pada stasiun II dan III melebihi ambang batas baku mutu $(0,03$ $\mathrm{mg} / \mathrm{L}$ ) dan lebih tinggi dibandingkan dengan stasiun I.

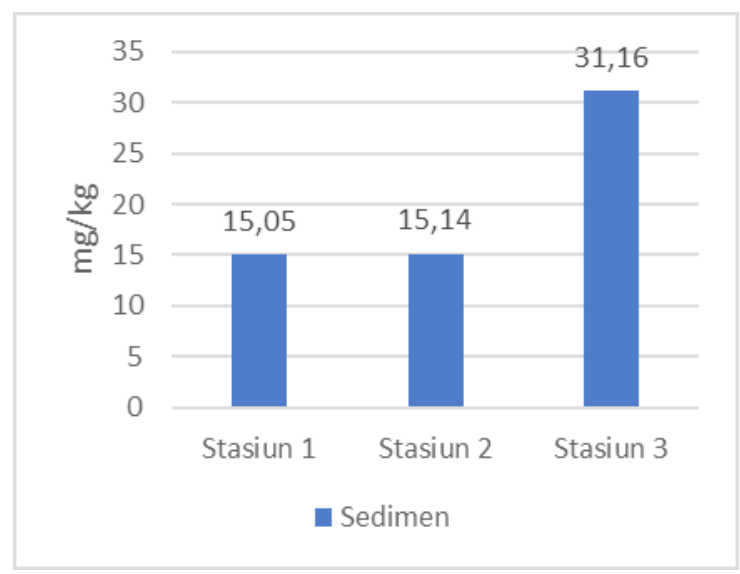

Gambar 2. Diagram Rata-rata Konsentrasi Logam Berat Timbal pada Sedimen.

Tabel 1. Kualitas air Sungai Winongo Kota Yogyakarta

\begin{tabular}{ccccc}
\hline & \multicolumn{3}{c}{ Stasiun } & $\begin{array}{c}\text { Baku Mutu } \\
\text { (PPRI No. 82 Th 2001) }\end{array}$ \\
\cline { 2 - 4 } & I & II & III & Deviasi 3 \\
Suhu & $27^{\circ} \mathrm{C}$ & $26,5^{\circ} \mathrm{C}$ & $27^{\circ} \mathrm{C}$ & $6-9$ \\
DO & 6,75 & 6,46 & 6,95 & $3 \mathrm{mg} / \mathrm{L}$ \\
Kecepatan Arus & $4,2 \mathrm{mg} / \mathrm{L}$ & $1,4 \mathrm{mg} / \mathrm{L}$ & $1,4 \mathrm{mg} / \mathrm{L}$ & - \\
\hline
\end{tabular}

PPRI : Peraturan Pemerintah Republik Indonesia. 
Pada Gambar 2 dapat dilihat konsentrasi logam berat timbal pada sedimen Sungai Winongo antar stasiun. Stasiun III yang merupakan daerah hilir sungai memiliki konsentrasi timbal yang lebih tinggi dibandingkan stasiun I (hulu) dan stasiun II (tengah). Pada sedimen, termasuk di bawah batas maksimum $50 \mathrm{mg} / \mathrm{kg}$ (ANZECC ISQGLow, 2000).

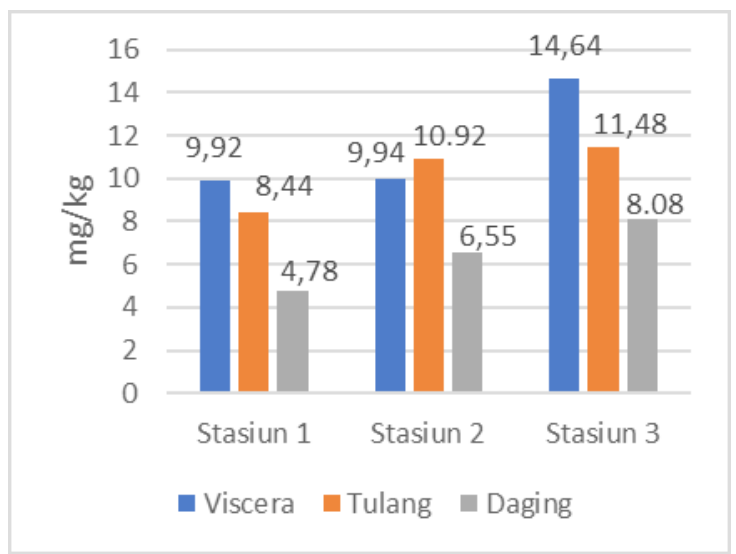

Gambar 3. Diagram Rata-rata Logam Berat Timbal pada Ikan Nila.

Pada Gambar 3 dapat dilihat rata-rata konsentrasi timbal pada tiga organ ikan Nila (viscera, tulang dan daging) di Sungai Winongo antar stasiun. Konsentrasi timbal pada ketiga organ ikan Nila telah melebihi ambang batas yang ditetapkan SNI (2009) dengan nilai $0,3 \mathrm{mg} / \mathrm{kg}$.

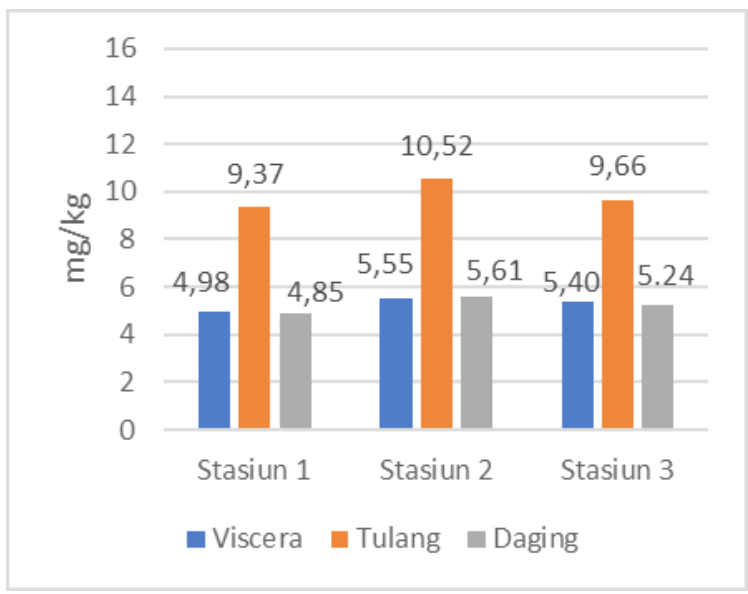

Gambar 4. Diagram Rata-rata Konsentrasi Logam Berat Timbal pada ikan Bawal.

Pada Gambar 4 terdapat hasil rata-rata konsentrasi timbal pada tiga organ ikan Bawal (viscera, tulang dan daging) di Sungai
Winongo antar stasiun. Konsentrasi timbal pada ketiga organ ikan Bawal melebihi ambang batas baku mutu yang ditetapkan oleh SNI (2009), dengan nilai sebesar 0,3 $\mathrm{mg} / \mathrm{kg}$.

\section{Pembahasan \\ Parameter Lingkungan}

Menurut Rochyatun (2003), selain dipengaruhi peningkatan jumlah sumber pencemaran, perubahan tingkat konsentrasi logam berat dalam air juga dipengaruhi oleh beberapa faktor seperti suhu, $\mathrm{pH}$, dissolved oxygen (DO) dan kecepatan aliran arus sungai. Naik dan turunnya suhu pada perairan tidak hanya mempengaruhi metabolisme biota air yang terdapat di dalamnya namun juga tingkat toksisitas suatu logam berat (Hutagalung, 1984).

Pada Tabel 1 oksigen terlarut merupakan oksigen yang dihasilkan dari hasil fotosintesis dan absorbsi dari udara (Effendi, 2003), jumlah oksigen terlarut berkisar 1,4 mg/L - 4,2 mg/L. Baku mutu air PPRI No. 82 Tahun 2001 tertulis bahwa kelarutan oksigen pada perairan kelas III untuk pembudidayaan ikan air tawar yakni sebesar $3 \mathrm{mg} / \mathrm{L}$, dibandingkan dengan baku mutu stasiun II dan III masih tergolong di bawah ambang batas kecuali stasiun I. Rendahnya jumlah oksigen terlarut dalam air juga dapat diindikasikan bahwa banyaknya pencemaran yang masuk ke dalam perairan.

Derajat keasaman $(\mathrm{pH})$ berfungsi sebagai faktor pembatas, dikarenakan setiap organisme memiliki batas toleransi masing-masing untuk bertahan hidup, nilai $\mathrm{pH}$ dapat digunakan untuk mengontrol tipe dan laju kecepatan reaksi bahan-bahan pada perairan (Sarjono, 2009). Derajat keasaman $(\mathrm{pH})$ dapat dipengaruhi oleh suhu, oksigen terlarut dan kandungan garam ionik perairan tersebut. Pada Tabel 1, nilai pH pada ketiga stasiun Sungai Winongo berkisar 6,5 - 7yang tergolong masih di dalam nilai ambang batas baku mutu PPRI No. 82 Tahun 2001 untuk kelas III yakni sebesar $6-9$. Peningkatan debit air dapat menyebabkan bahan-bahan alam terlarut ke badan air akibat erosi yang meningkat secara eksponensial, berbeda dengan bahan antropogenik yang akan 
mengalami penurunan saat memasuki badan air diakibatkan proses pengenceran (Effendi, 2003). Kecepatan arus tertinggi yakni pada stasiun I sebesar $0,47 \mathrm{~m} / \mathrm{s}$ diikuti stasiun II $0,29 \mathrm{~m} / \mathrm{s}$ dan stasiun III $0,08 \mathrm{~m} / \mathrm{s}$.

\section{Konsentrasi Logam Berat Timbal pada Sungai Winongo}

Pada Gambar 1 dapat dilihat Sungai Winongo yang konsentrasi airnya berkisar antara 0,02 mg/L - 0,08 mg/L, sedangkan pada Gambar 2 terlihat sedimen memiliki konsentrasi logam berat yang lebih besar yang berkisar antara $12 \mathrm{mg} / \mathrm{kg}-36 \mathrm{mg} / \mathrm{kg}$. Kasari (2016) menyatakan, bahwa kandungan logam berat timbal $(\mathrm{Pb})$ akan lebih besar konsentrasinya pada sedimen dibandingkan dengan air. Hal ini dimungkinkan terjadi oleh karena proses pengendapan dan sedimentasi yang terjadi. Partikel-partikel logam berat dalam kolom air akan mengalami penggabungan dengan senyawa lain seperti bahan organik maupun anorganik yang dapat meningkatkan massa jenis menjadi besar sehingga terjadi proses pengendapan dan sedimentasi. Kedua proses tersebut dapat menyimpulkan bahwa sedimen merupakan tempat terjadinya akumulasi pada perairan.

Logam berat pada perairan Sungai Winongo Hulu (Stasiun I) memiliki nilai yang tidak melebihi ambang batas baku mutu yang ditetapkan oleh PPRI No. 82 Tahun 2001 yakni 0,03 mg/L, sedangkan pada stasiun II dan III memiliki nilai yang melebihi batas baku mutu. Hal ini akibat logam berat yang mengalami pengendapan dikarenakan pergerakan air yang bergerak dari tinggi ke rendah sehingga menyebabkan pengendapan pada bagian yang lebih rendah (Vandra et al, 2016). Pada sedimen, termasuk di bawah batas maksimum $50 \mathrm{mg} / \mathrm{kg}$ (ANZECC ISQG-Low, 2000). Darmono (2011) menyatakan, logam berat timbal memiliki kelarutan yang rendah degan beberapa anion dalam air, selain itu rendahnya konsentrasi logam berat pada perairan juga dapat terjadi karena adanya sifat alami sungai yaitu memulihkan diri sendiri atau Self Purification.

Pemulihan diri sendiri merupakan kemampuan dalam mengurangi maupun menghilangkan bahan organik, nutrisi tanaman maupun bahan pencemar lainnya dari suatu danau atau sungai yang disebabkan oleh adanya aktivitas biologis dari komunitas biota maupun tanaman air di dalamnya. Hal ini juga didukung dengan pergerakan air sungai dari tinggi ke rendah sehingga membawa bahan-bahan anorganik maupun organik tersebut larut bersamanya (Vandra et al, 2016). Mukhtasor (2007) menyatakan, bahwa aliran arus sungai akan mempengaruhi distribusi logam berat, semakin cepat arus sungai maka konsentrasi logam berat akan cenderung lebih rendah dikarenakan lebih terdistribusi merata, hal ini terjadi pada stasiun I dan II yang memiliki kecepatan arus yang cukup tinggi. Menurut Hutagalung (1994), logam berat cenderung mengendap ke dasar perairan pada kondisi perairan yang tenang. Hal ini terjadi pada stasiun III (Winongo Hilir) dengan kondisi perairan yang tenang, sehingga potensial pengendapan lebih tinggi menyebabkan konsentrasi logam berat pada sedimen cukup tinggi dibandingkan dengan stasiun I dan II.

\section{Kosentrasi Logam Berat Timbal pada Ikan Nila (Oreochromis niloticus)}

Logam berat yang terabsorbsi oleh tubuh makhluk hidup akan mengalami biokonsentrasi, biomagnifikasi dan bioakumulasi Biokonsentrasi merupakan proses masuknya bahan pencemar ke tubuh makhluk hidup secara langsung melalui saluran pernapasan atau kontak langsung dengan kulit. Biomagnifikasi terjadi ketika konsentrasi suatu bahan pencemar meningkat dengan meningkatnya posisi suatu makhluk hidup tersebut pada sistem rantai makanan. Bioakumulasi adalah makhluk hidup yang terpapar bahan pencemar dari lingkungan melalui suatu mekanisme seperti sifat fisiologis ikan yakni logam berat yang terakumulasi pada saluran pencernaan ikan oleh karena makanan yang dikonsumsi telah terpapar logam berat. Bioakumulasi terjadi pada jaringan tubuh akibat terabsorbsinya bahan pencemar tersebut oleh tubuh makhluk hidup melalui air atau makanan yang dikonsumsinya (Connel dan Miller, 2006). 
Terjadinya bioakumulasi suatu biota air disebabkan oleh beberapa faktor seperti lingkungan perairan, makanan, jenis ikan, ekskresi dan metabolisme. Ikan Nila merupakan ikan pemakan segala (omnivora) sehingga potensi terakumulasi logam berat lebih tinggi (Hidayah, 2012). Menurut penelitian Noegrohati (2006), bioakumulasi yang terjadi pada ikan Nila bahwa logam berat secara dinamis mempunyai nilai bioakumulasi masing-masing tergantung jenis logam dan kondisi lingkungan perairannya.

Pada Gambar 3 konsentrasi logam berat timbal pada ikan Nila tertinggi terdapat pada organ viscera dibandingkan dengan tulang dan daging, sedangkan konsentrasi timbal pada ketiga organ ikan Nila telah melebihi ambang batas yang ditetapkan SNI (2009) dengan nilai $0,3 \mathrm{mg} / \mathrm{kg}$. Hal ini sesuai dengan pernyataan Darmono (2001), Akumulasi logam berat tertinggi biasa terdapat pada jaringan hati dan ginjal. Hal ini dikarenakan hati merupakan pintu masuk semua bahan ke dalam tubuh, sehingga organ ini memiliki potensi keracunan yang lebih tinggi dibandingkan dengan organ lainnya (Robbins, 1995). Loomis (1978), menyatakan bahwa hati merupakan organ vital yang memiliki fungsi detoksifikasi dan mensekresikan bahan kimia untuk proses pencernaan. Al Nagaawi (2008), menyatakan bahwa ikan mempunyai beberapa regulasi diantaranya ekskresi, detoksifikasi dan penyimpanan. Detoksifikasi yang dilakukan organ hati ikan adalah mengikat logam (metallothionein) di dalam jaringan. Menurut Lu (2010), sebagian besar senyawa toksik yang terabsorbsi akan diserap oleh sel epitel usus halus lalu didistribusikan ke hati oleh vena porta hati, tinggi absorbsi logam berat dapat menurunkan kemampuan hati untuk mengekskresikan toksikan tersebut.

\section{Konsentrasi Logam Berat Timbal pada Ikan Bawal}

Pada Gambar 4 dapat dilihat bahwa rata-rata konsentrasi logam berat timbal tertinggi ada pada bagian tulang ikan Bawal dibandingkan dengan organ viscera dan daging. Ketiga bagian ikan Bawal yang diteliti yakni viscera, tulang, dan daging memilki konsentrasi timbal melebihi ambang batas baku mutu yang ditetapkan oleh SNI (2009), dengan nilai sebesar 0,3 mg/kg. Meski timbal yang terabsorbsi tidak dalam jumlah banyak, logam berat ini memiliki toksisitas yang cukup tinggi. Hal ini dikarenakan senyawa timbal dapat mengganggu fungsi organ dalam tubuh ikan (Palar, 1994). Di dalam tubuh, timbal berbentuk ion $\mathrm{Pb}^{2+}$ yang mampu mengganti posisi ion $\mathrm{Ca}^{+}$pada tulang. Secara umum tulang merupakan tempat pengendapan timbal pada semua makhluk hidup. Timbal yang mengendap akan bergabung dengan matrik tulang yang mirip dengan $\mathrm{Ca}^{+}$. Timbal dalam tulang berpotensi mencapai 95\% dari seluruh timbal yang terdapat pada bagian tubuh makhluk hidup (Depkes RI, 2001). Faktor lain yang dapat mempengaruhi gangguan pada pertumbuhan tulang adalah kelainan genetik dan senyawa toksik seperti logam berat pada perairan (Zulfahmi et al, 2018).

Konsentrasi timbal pada daging ikan dikaitkan dengan fungsi fisiologis dalam metabolisme ikan. Daging tidak termasuk jaringan aktif yang mengakumulasi timbal berbeda dengan organ viscera seperti hati dan ginjal yang berperan utama dalam dektosifikasi dan ekskresi sehingga berpotensi lebih tinggi terakumulasi (Khaled, 2004). Didukung oleh pernyataan Arain (2008) bahwa logam berat pada ikan akan lebih tinggi konsentrasinya pada bagian tulang dan kepala dibandingkan pada daging. Akumulasi logam berat pada ikan terjadi melalui proses respirasi, konsumsi makanan, dan kontak langsung antara air dengan kulit ikan (Priatna et al, 2016).

Berdasarkan statistik perbedaan konsentrasi logam berat timbal antara air, sedimen dan bagian tubuh ikan (viscera, tulang, dan daging) setiap stasiun cukup signifikan. Perbedaan setiap rata-rata menunjukkan hasil signifikan kecuali pada rata-rata antara sedimen stasiun 1 dan sedimen stasiun II yang tidak menunjukkan perbedaan cukup signifikan. Hal ini dimungkinkan oleh beberapa faktor salah satunya kecepatan arus seperti pada stasiun I $(0,47 \mathrm{~m} / \mathrm{s})$ dengan stasiun II $(0,29$ 
m/s) tidak berbeda jauh. Kecepatan arus dapat menyebabkan bahan-bahan alam terlarut ke badan air akibat erosi yang meningkat secara eksponensial, berbeda dengan bahan antropogenik yang akan mengalami penurunan saat memasuki badan air diakibatkan proses pengenceran (Effendi, 2003). Mukhtasor (2007), menyatakan bahwa pergerakan air sungai dari tinggi ke rendah mempengaruhi distribusi logam berat, semakin cepat arus sungai maka konsentrasi logam berat akan cenderung lebih rendah dikarenakan lebih terdistribusi merata.

\section{Kesimpulan}

Konsentrasi logam berat timbal pada saat pengambilan sampel air dan ikan (bagian viscera, tulang dan daging) di Sungai Winongo telah melebihi batas baku mutu $(0,3 \mathrm{mg} / \mathrm{kg})$, sedangkan sedimen masih di bawah baku mutu (50 mg/kg).

\section{Daftar Pustaka}

Ackerley, D. F., Gonzales, C. F., Park, C. H., Blake, R., Keyhan, M, \& Martin, A. (2004). Chromat Reducing Properties of Soluble Flavoprotein from Pseudomonas Putida and Escherichia coli. Applied and Environmental, 70(2), 873-882.

Al-Nagaawy, A. M. (2008). Accumulation and Elimination of Copper and Lead from Oreochromis niloticus Fingerlings and Consequent Influence on Their Residues and Some Biochemical Parameters. $8^{\text {th }}$ International Symposium on Tilapia in Aquaculture, pp.431-445.

Arain, M. B., T. G. Kazi., M. K. Jamali., N. Jalbani., H. I. Afridi, \& A. Shah. (2008). Total Dissolved and Bioavailable Elements in Water and Sediment Samples and Their Accumulation in Oreochromis mossambicus of Polluted Manchar Lake. Chemosphere, 70(10), 1845-1856.

Arie, U. (2006). Budidaya Bawal Air Tawar Untuk Konsumsi dan Hias. Jakarta: Penebar Swadaya.

Australian and New Zealand Environment and Conservation Council (ANZECC). (2000). ANZECC Interim Sediment Quality Guidlines. Sydney, Australia.
Badan Lingkungan Hidup Propinsi Daerah Istimewa Yogyakarta. (2012). Laporan Pemantauan Kualitas Air Sungai Provinsi Daerah Istimewa Yogyakarta. Yogyakarta: BLH DIY.

Connel \& Miller. (2006). Kimia dan Ekotoksikologi Pencemaran. (Y. Koestoer, Ed.). Jakarta: Universitas Indonesia Press.

Darmono. (2001). Lingkungan Hidup dan Pencemaran Hubungannya dengan Toksikologi Senyawa Logam. Jakarta: UI Press.

Departemen Kesehatan RI. (2001). Kerangka Acuan Uji Petik Kadar Timbal (Pb) pada Spesimen Darah terhadap Kelompok Masyarakat Beresiko Tinggi Pencemaran Timbal. Jakarta.

Effendi, H. (2003). Telaah Kualitas Air Bagi Pengelolaan Sumber daya dan Lingkungan Perairan.

Grossel, M., R. M Gerdes, \& K. V Brix. (2005). Chronic Toxicity of Lead to Three Freshwater Intervertebrates - Brachionus calcyciflorus, Chironomous tetans and Lymnaea stagnalis. Environmental Toxicology and Chemistry, 25(1), 97-104.

Hidayah, A. M., Purwanto, \& Tri Retnaningsih, S. (2012). Kandungan Logam Berat pada Air, Sedimen dan Ikan Nila (Oreochromis niloticus Linn.) di Karamba Danau Rawapening. Seminar Nasional Pengelolaan Sumber Daya Alam dan Lingkungan.

Huang P. T. G. Li., Li. X., K. Yu, \& N. J. Hu. (2012). Distribution, enrichment and sources of Heavy Metals in Surface Sediments of The North Yellow Sea. Amsterdam: Elsevier Sci, 73, 1-13.

Hutabarat, H. P. (2011). Evaluasi LogamLogam Berat Tanah yang diaplikasikan Limbah Cair Pabrik Kelapa Sawit.

Hutagalung H. P. (1994). Kandungan Logam Berat dalam Sedimen di Kolam Pelabuhan Tanjung Priok. Makalah Penunjang Seminar Pemantauan Pencemaran Laut . Jakarta: P3O-LIPI.

Hutagalung, H., Riyono, S.H, \& Setiapermana, D. (1997). Metode Analisis Air Laut Sedimen dan Biota. Pusat Penelitian dan Pengembangan Oseanologi LIPI. 
Hutagalung, P. H. (1984). Logam Berat dalam Lingkungan Laut. Pewarta Oceana, 9(1), pp. 11-20.

Ibisch, R \& Borchardt, D. (2009). Integrated Water Resources Management (IWRM) : From Research to Implementation.

Ivanciuc, T., Ovidiu, I., \& Douglas J. Klein. (2006). Modelling the Bioconcentration Factor and Bioaccumulation Factor of Polychlorinated Biphenyls with Posetic Quantitative Super Structure/Activity Relationship (QSSAR). Molecular Diversity, 10, 133-145.

Jaishankar, M., Mathew, B.B., Shah, M. S., \& Gowda, K. R. S. (2014). Biosorption of Few Heavy Metal Ions Using Agricultural Wastes. Environment Pollution and Human Health, 2 (1), 1-6.

Kasari, A. F. (2016). Status Pencemaran Berdasarkan Logam Berat Pb, Hg, Cd, $\mathrm{Cu}$, dan Ag Dalam Air dan Sedimen di Estuari Sungai Donan, Segara Anakan Timur. Bogor: IPB.

Khaled, A. (2004). Heavy Metal Concentration in Certain Tissues of Mullus Barbatus and Sparus Aurata Collected from Iskenderun Gulf (Turkey). Water, Air and Soil Pollution, 90, 557-562.

Koestoer, Y. (1995). Kimia dan Ekotoksikologi Pencemaran. (D. Connel, Trans.) Jakarta: UI Press.

Kriswantoro, M. (1986). Mengenal Ikan Air Tawar. Jakarta : B. P Karya Bani - Jakarta OXXIII.

Loomis, F. (1978). Environmental Psychology. Philadelphia: W.B Saunders.

Lu, F. C. (2010). Toksikologi Dasar : Asas, Organ, Sasaran dan Penliaian Risiko (2 ed.). (E. Nugroho, Trans.) Jakarta: UI Press.

Manahan, S. E. (2002). Environmental Chemistri (7 ed.). New York: Lewis.

Moriaty, F \& H. M. Hanson. (1988). Heavy Metals in Sediments of The River Ecclesbourne, Drbyshire. ELSEVIER: Water Research, 22(4), 475-480.

Mukhtasor. (2007). Pencemaran Pesisir dan Laut. Jakarta: PT. Pradnya Paramitha.

Noegrohati, S. (2006). Bioaccumulation Dynamic of Heavy Metals in Oreochromis Nilotycus. Indonesian Journal of Chemistry,
6(1), 61-69.

Oktapiandi, J., Sutrisno., \& Sunarto. (2019). Analisis Pertumbuhan Ikan Nila yang dibudidayakan Pada Air Musta'mal. Bioeksperimen, 5(1), 16-20.

Palar. (1994). Pencemaran dan Toksikologi Logam Berat . Jakarta: Rineka Cipta.

PPRI No. 82 Tahun 2001. (2001). Pengelolaan Kualitas Air dan Pengendalian Pencemaran Air.

Pramana, J. D., A. Taftazani., \& Sudamardji. (2000). Sebaran Logam Berat dalam Culikan Air Laut, Algae dan Ikan di Daerah Semenanjung Muria. Pertemuan dan Presentasi Ilmiah Penelitian Dasar Ilmu Pengetahuan dan Teknologi Nuklir. Yogyakarta: P3tm-Batan.

Priatna, D. E., Purnomo, T., \& Kuswanti, N. (2016). Kadar Logam Berat Timbal (Pb) pada Air dan Ikan Bader (Barbpnymus gonionotus) di Sungai Brantas Wilayah Mojokerto. Lentera Bio, 5(1), 48-53.

Purnomo, T \& Muchyiddin. (2007). Analisa Kandungan Timbal $(\mathrm{Pb})$ pada Ikan Bandeng (Chanos chanos) di Tambak Kecamatan Gresik. Majalah Ilmiah Kelautan, 14(1), 69-77.

Robbins \& Kumar. (1995). Buku Ajar Patologi (4 ed., Vol. 1). Jakarta.

Rochyatun, E., Edward., \& A. Rozak. (2003). Kandungan Logam Berat $\mathrm{Pb}, \mathrm{Cd}$, $\mathrm{Cu}, \mathrm{Zn}, \mathrm{Ni}, \mathrm{Cr}, \mathrm{Mn}$ dan Fe Dalam Air Laut dan Sedimen di Perairan Kalimantan Timur. Jakarta: Oseanologi dan Limnologi P2o-LIPI.

Sahetapy, J. M. (2011). Toksisitas Logam Berat Timbal $(\mathrm{Pb})$ dan Pengaruhnya pada Konsumsi Oksigen dan Respon Hematologi Juvenil Ikan Kerapu Macan [skripsi]. Institut Pertanian Bogor, Bogor, Indonesia.

Setiyono. (2004). Pedoman Teknis Pengelolaan Limbah Industri Kecil. Jakarta: Kementerian Lingkungan Hidup.

Supriyatno., Samin, C., \& Kamal, Z. (2007). Analisis Cemaran Logam Berat $\mathrm{Pb}$, $\mathrm{Cu}$, dan $\mathrm{Cd}$ pada Ikan Air Tawar, dengan Metode Spektrometri Nyala Serapan Atom (SSA). Prosiding Seminar Nasional III SDM Teknologi Nuklir, 
hlm. 147-152.

Ulfin, I. (2001). Penyerapan Logam Berat Timbal dan Kadmium dalam Larutan Kayu Apu (Pistia stratiotes L). 2(1), 1-25. Vandra, B., Sudarno., \& Winardi, D. N. (2016). Studi Analisis Kemampuan Self Purification pada Sungai Progo Ditinjau dari Parameter Biological Oxygen Demand (BOD) dan Dissolved Oxygen (DO). Teknik Lingkungan, 5(4), 2-3.

Zulfahmi, I., Akmal, Y., \& Batubara, A. S. (2018). The Morphology of Thai Mahseer's Tor Tambroides Axial Skeleton (Ossa Vertebrae). Iktiologi, 18(2),139-149. 